\title{
EFFECT OF SOME MEDICINAL PLANTS AS FEED ADDITIVES ON LACTATING AWASSI EWE PERFORMANCE, MILK COMPOSITION, LAMB GROWTH AND RELEVANT BLOOD ITEMS
}

\author{
Safaa S. EL-Ghousein \\ Jerash Private University, Faculty of Agriculture, Jerash, Jordan
}

\section{SUMMARY}

Milk production and composition, lamb growth, blood hematological profile and relevant blood metabolites were assayed in Awassi ewes and lambs as affected by supplementing basal diet by either chamomile flowers $(C F)$ or Nigella sativa seeds (NSS). Twenty-one pregnant Awassi ewes of similar weight ( $B W$ around $50 \mathrm{Kg}$ ) and age (45-48 months) were equally divided into three dietary treatments. Group (1) served as a control group received basal diet (BD) with no feed supplement. Groups (2) (CF) and (3) (NSS) received $10 \mathrm{~g} /$ ewe / day (CF) or (NSS), respectively. Lactation period and milk yield were higher $(P<0.05)$ in ewes of $(C F)$ supplement followed by that of (NSS) supplement than that of basal diet only, respectively. Whereas, weaning weight $(W W)$ and average daily gain $(A D G)$ of lambs were improved $(P<0.05)$ by the addition of $(C F)$ or (NSS) to the basal diet. The addition of $(C F)$ and $(N S S)$ increased $(P<0.05)$ WBC's and lymphocytes counts of these lactating ewes, while, monocytes count was higher $(P<0.05)$ in ewes fed basal diet only. No significant effects were noticed on eiosinophils, RBC's count and $\mathrm{Hb}$ concentration in ewes fed the supplemented diets. $R B C$ 's, WBC's, lymphocytes counts and $\mathrm{Hb}$ concentration of suckling lambs were improved $(P<0.05)$ by adding $(C F)$ or (NSS) to the basal diet of ewes. Addition of (CF) or (NSS) to the basal diet increased $(P<0.05)$ blood serum; total protein and globulin concentration of these ewes compared to those of control group. However, no significant differences were observed in albumin, glucose, triglycerides and urea concentrations. Total serum cholesterol was decreased $(P<0.05)$ by the addition of $(C F)$ and (NSS). Concerning suckling lambs, the addition of $(C F)$ or (NSS) to the basal diet increased $(P<0.05)$ total protein and globulin concentration, while, it decreased albumin: globulin ratio. No significant effects were noticed in albumin, glucose, triglycerides and cholesterol of suckling lambs blood serum. It is concluded that (CF) and (NSS) diet supplement could be used as natural growth promoters in ewe diets to improve milk yield and composition and lamb growth.

Keywords: Awassi ewes, chamomile flowers, Nigella sativa, supplements

\section{INTRODUCTION}

Milk production of sheep is of great importance for lamb production because of its direct effect on young growth, particularly during early weeks of their life. Economic sheep production in Jordan is largely based on the supply of milk sold commercially for the production of cheese and other products. Many attempts have 
been made to achieve increase in milk production and thereby profits. Feed supplements, hormones, minerals and feed additives were used. Bovine Somatotropins administration to healthy dairy animals is reported to increase milk production (Lurdi, 1993), but such a treatment is very expensive and the milk from treated cattle may not be safe for human consumption (Kronfeld, 1991).

The use of herbal galactogogues is known to have beneficial effect on milk production (Singh et al., 1993 and Tiwari et al., 1993). Vihan and Panwar (1987) reported that Nigella sativa seeds (NSS) might be useful galactogogues for lactating goats. Allam et al. (1999) observed that using herbs such as chamomile in dairy animal diet had a positive effect on milk production and efficiency of feed conversion as well. Moreover, serum cholesterol and total lipids were reduced as a result of chamomile flowers (CF) addition to the diet (EL-Hosseiny et al., 2000). The same authors also reported that the use of $(\mathrm{CF})$ in doe rations reduced mortality rate of born kids to zero during suckling period compared to other medicinal herbs which suggests that chamomile may have a role in improving immunity and performance of kids. Shehata et al. (2004) reported that milk yield and all assayed components tended to be increased by the addition of $(\mathrm{CF})$ to goat's diets.

This work was designed to evaluate the effect of (CF) and (NSS) galactogogues addition to lactating Awassi ewe diets; on milk yield and composition and relevant blood metabolites, as well as lambs growth.

\title{
MATERIALS AND METHODS
}

The experimental work was carried out at the Department of Animal Production, Faculty of Agriculture, Jerash Private University, Jerash, Jordan.

\begin{abstract}
Animals and feeds
Twenty-one pregnant Awassi ewes with body weight around $50 \mathrm{Kg}$ and 45-48 months of age were treated at late gestation, two weeks before lambing, were randomly divided into equql three dietary groups. The first group was fed the basal diet (BD) and served as a control group. The second group was fed the basal diet supplemented by $10 \mathrm{~g} /$ ewe / day chamomile flowers (CF), while, the third group was fed basal diet supplemented by $10 \mathrm{~g} /$ ewe / day Nigella sativa seeds (NSS). Each group was housed in a semi-roofed barn $(5 \times 4 \times 4 \mathrm{~m})$. The daily basal diet (BD) at experimental start was $1.2 \mathrm{Kg}$ concentrate and $0.5 \mathrm{Kg}$ straw / ewe / day offered in two equal meals, at 09:00 and 15:00 hr. The ration was increased biweekly by $0.2 \mathrm{Kg}$ concentrate and $0.3 \mathrm{Kg}$ straw / ewe / day until weaning. Extra addition of $10 \mathrm{~g} /$ day of (CF) or (NSS) was added when lambs reached one month of age to ensure that the lambs consume considerable amount of additives. Table (1) shows the composition of concentrate feed. The study was started two weeks before parturition and lasted till the end of lactation.
\end{abstract}

\section{Milking assessments}

Starting from the end of the first week (after colostrum) lambs were isolated from their dams in separate pens after the second meal (15:00 hr) till the next day. At weekly intervals complete milking was done at morning till stripping by hand, thus milk yield was recorded throughout the lactation period. Milk samples were obtained for analysis. Fat, protein and ash percentages were determined using the method 
described by Ling (1963), and lactose percentage by the procedure of Barnett and Abd AL-Tawab (1957). Total solids not fat were calculated.

Table 1. Formulation of concentrate feed mixture, and proximate analysis of the basal diet (BD)

\begin{tabular}{lclc}
\hline Components & \% & Proximate analysis & \\
\hline Barley grain & 69.0 & Dry matter \% (DM) & 88.55 \\
Wheat bran & 14.0 & Organic matter \% (DM) & 94.55 \\
Soybean meal & 14.6 & Components \% of DM & \\
Calcium Carbonate & 1.3 & Ash \% & 5.45 \\
Sodium Chloride & 0.5 & Crude protein \% & 13.60 \\
Calcium Phosphate & 0.5 & Either extract \% & 4.66 \\
Trace elements \& Vitamins & 0.1 & Crude fiber \% & 8.40 \\
\multicolumn{1}{c}{ Total } & & Nitrogen free extract (NFE)\% & 67.89 \\
\hline
\end{tabular}

Lamb growth

Lambs were weighed at birth, and weekly till weaning at 60 days of age. Daily weight gain was calculated.

\section{Blood samples collection}

Ewes of each dietary treatment group were used for blood assessments. Blood samples were collected from the jugular vein of each ewe at the beginning of the experiment, after lambing and at monthly intervals till weaning (60 days). Part of the blood was received into EDTA anticoagulant tubes for the determination of hematological items. The other part of blood was collected in non-heparinized tubes and then centrifuged at $4000 \mathrm{rpm}$ for three minutes. Clear serum was separated and stored at $\left(-20{ }^{\circ} \mathrm{C}\right)$ for blood chemical assays. The same procedure was used with lambs at three days of age then biweekly till weaning.

\section{Determination of blood relevant metabolites concentrations}

Serum total protein concentration was determined by Biuret method using kits of (Chemelex, Barcelona). Special kits from (Chemelex, Barcelona) were also used for the determination of; albumin, globulin, urea and glucose concentrations. Albumin: globulin ratio $(\mathrm{A} / \mathrm{G})$ was calculated. Serum total cholesterol concentration was assayed spectrophotometrically using kits from (Bio Mereuxas, France). Serum triglycerides concentration was determined by triglyceride-GPO method using kits from (Biolabosa, France) after hydrolysis with lipase.

\section{Determination of blood hematological items}

The determination of hematological items, white blood cells (WBC's) total and differential counts, red blood cells (RBC's) count and hemoglobin (Hb) concentration were determined according to Wintrobe (1976).

\section{Statistical analysis}

A completely randomized statistical design was used. Collected data were statistically analyzed by analysis of variance (ANOVA) by the statistical package SPSS for Windows (2001), standard version. 


\section{RESULTS}

\section{Milk production and composition}

Ewes fed basal diet (BD) supplemented with $(\mathrm{CF})$ had the longest $(\mathrm{P}<0.05)$ lactation period and the greatest milk yield compared to those fed either the basal diet or the basal diet supplemented with (NSS) (Table 2). The use of (CF) and (NSS) as natural feed additives increased $(\mathrm{P}<0.05)$ total protein $(\mathrm{TP})$, solids not-fat $(\mathrm{SNF})$ and ash (A) percentages compared to control group. However, no significant effects were noticed in lactose (L) and total solids (TS) as a result of (CF) and (NSS) supplementation.

Table 2. Milk production and composition of lactating Awassi ewes as affected by dietary treatments (Means \pm SE)

\begin{tabular}{lccc}
\hline \multirow{2}{*}{ Items } & \multicolumn{2}{c}{ Dietary } & \multicolumn{2}{c}{ treatments } \\
\cline { 2 - 4 } & Control & $\begin{array}{c}\text { Chamomile } \\
\text { flowers }\end{array}$ & $\begin{array}{c}\text { Nigella sativa } \\
\text { seeds }\end{array}$ \\
\hline Lactation period (d) & $68.0 \pm 3.7^{\mathrm{c}}$ & $92.0 \pm 3.8^{\mathrm{a}}$ & $83.0 \pm 2.0^{\mathrm{b}}$ \\
Total milk yield (Kg) & $256.3 \pm 20.1^{\mathrm{c}}$ & $490.9 \pm 39.8^{\mathrm{a}}$ & $349.9 \pm 28.7^{\mathrm{b}}$ \\
Fat \% (F) & $5.41 \pm 0.47$ & $5.20 \pm 0.48$ & $4.87 \pm 0.33$ \\
Total protein \% (TP) & $4.84 \pm 0.11^{\mathrm{b}}$ & $5.45 \pm 0.13^{\mathrm{a}}$ & $5.47 \pm 0.12^{\mathrm{a}}$ \\
Lactose \% (L) & $3.99 \pm 0.16$ & $3.97 \pm 0.08$ & $4.20 \pm 0.10$ \\
Total solids\% (TS) & $15.12 \pm 0.44$ & $15.60 \pm 0.51$ & $15.52 \pm 0.34$ \\
Solids not-fat \% (SNF) & $9.71 \pm 0.21^{\mathrm{b}}$ & $10.40 \pm 0.16^{\mathrm{a}}$ & $10.65 \pm 0.11^{\mathrm{a}}$ \\
Ash \% (A) & $0.88 \pm 0.02^{\mathrm{b}}$ & $0.98 \pm 0.01^{\mathrm{a}}$ & $0.98 \pm 0.02^{\mathrm{a}}$ \\
\hline
\end{tabular}

${ }^{\mathrm{a}-\mathrm{c}}$ Means with different superscripts in the same row are significantly different at $\mathrm{P}<0.05$.

\section{Lambs Growth performance}

Table (3) presents the means \pm SE of lamb birth weight (LBW), weaning weight (WW) and average daily gain (ADG). Addition of Chamomile flowers (CF) or Nigella sativa seeds (NSS) to basal diet improved $(\mathrm{P}<0.05) \mathrm{WW}$ and ADG of lambs compared to non-supplemented control diet.

\section{Blood serum metabolites}

Tables (4 and 5) show the concentrations of relevant blood serum metabolites of these ewes and their lambs. Addition of (NSS) and (CF) to the basal diet increased $(\mathrm{P}<0.05)$ serum total protein and globulin of both ewes and lambs. However, no significant differences were noticed in albumin, glucose, urea and triglycerides values of ewes and lambs serum among all treatments. Furthermore, serum cholesterol of ewes was decreased significantly $(\mathrm{P}<0.05)$ by the addition of $(\mathrm{NSS})$ and $(\mathrm{CF})$ while insignificant increase was found in lamb blood serum. Albumin: globulin ratio of ewes was increased $(\mathrm{P}<0.05)$, opposite to the trend observed in lambs, by supplementing the basal diet with these additives. 
Table 3. Growth performance of suckling Awassi lambs as affected by dietary treatments (Means $\pm \mathrm{SE})$ $(n=7 /$ group $)$

\begin{tabular}{lccc}
\hline \multirow{2}{*}{ Items } & \multicolumn{2}{c}{ Dietary } & treatments \\
\cline { 2 - 4 } & Control & $\begin{array}{c}\text { Chamomile } \\
\text { flowers }\end{array}$ & $\begin{array}{c}\text { Nigella sativa } \\
\text { seeds }\end{array}$ \\
\hline Birth weight $(\mathrm{Kg})$ & $4.59 \pm 0.19$ & $4.66 \pm 0.21$ & $4.77 \pm 0.25$ \\
Weaning weight $(\mathrm{Kg})$ & $15.64 \pm 0.81^{\mathrm{b}}$ & $20.14 \pm 0.86^{\mathrm{a}}$ & $20.29 \pm 1.15^{\mathrm{a}}$ \\
Average daily gain $(\mathrm{Kg})$ & $0.185 \pm 0.01^{\mathrm{b}}$ & $0.258 \pm 0.01^{\mathrm{a}}$ & $0.259 \pm 0.02^{\mathrm{a}}$ \\
\hline${ }^{\mathrm{a}-\mathrm{b}}$ Means with different superscripts in the same row are significantly different at $\mathrm{P}<0.05$.
\end{tabular}

Table 4. Concentrations of relevant metabolites in blood serum of lactating Awassi ewes as affected by dietary treatments (Means \pm SE) $(n=7 /$ group)

\begin{tabular}{|c|c|c|c|}
\hline \multirow[b]{3}{*}{ Items } & \multicolumn{3}{|c|}{ Dietary treatments } \\
\hline & & & \\
\hline & Control & $\begin{array}{c}\text { Chamomile } \\
\text { flowers }\end{array}$ & $\begin{array}{c}\text { Nigella sativa } \\
\text { seeds }\end{array}$ \\
\hline Total protein $(\mathrm{gm} / \mathrm{dl})$ & $8.14 \pm 0.50^{b}$ & $9.95 \pm 0.75^{\mathrm{a}}$ & $9.85 \pm 0.55^{\mathrm{a}}$ \\
\hline Albumin (gm/dl) & $3.63 \pm 0.39$ & $4.36 \pm 0.36$ & $4.85 \pm 0.35$ \\
\hline Globulin (gm/dl) & $4.62 \pm 0.32^{\mathrm{b}}$ & $5.79 \pm 0.30^{\mathrm{a}}$ & $5.89 \pm 0.31^{\mathrm{a}}$ \\
\hline Albumin: Globulin (A:G) ratio & $0.79 \pm 0.03^{\mathrm{b}}$ & $0.84 \pm 0.03^{\mathrm{a}}$ & $0.82 \pm 0.04^{\mathrm{ab}}$ \\
\hline Glucose $(\mathrm{mg} / \mathrm{dl})$ & $75.8 \pm 4.04$ & $85.43 \pm 1.22$ & $80.61 \pm 6.04$ \\
\hline Urea (mg/dl) & $64.37 \pm 6.28$ & $66.73 \pm 9.62$ & $69.66 \pm 7.61$ \\
\hline Triglycerides (mg/dl) & $53.28 \pm 5.48$ & $54.26 \pm 4.42$ & $60.11 \pm 5.42$ \\
\hline Cholesterol (mg/dl) & $89.30 \pm 5.12^{\mathrm{a}}$ & $62.56 \pm 6.89^{\mathrm{b}}$ & $63.00 \pm 6.00^{\mathrm{b}}$ \\
\hline
\end{tabular}

${ }^{\mathrm{a}-\mathrm{b}}$ Means with different superscripts in the same row are significantly different at $\mathrm{P}<0.05$.

Table 5. Concentrations of relevant metabolites in blood serum of suckling Awassi lambs as affected by dietary treatments (Means $\pm \mathrm{SE}) \quad(n=7 /$ group $)$

\begin{tabular}{lccc}
\hline \multirow{2}{*}{ Items } & \multicolumn{2}{c}{ Dietary } & \multicolumn{2}{c}{ treatments } \\
\cline { 2 - 4 } & Control & $\begin{array}{c}\text { Chamomile } \\
\text { flowers }\end{array}$ & $\begin{array}{c}\text { Nigella sativa } \\
\text { seeds }\end{array}$ \\
\hline Total protein $(\mathrm{gm} / \mathrm{dl})$ & $6.60 \pm 0.86^{\mathrm{b}}$ & $9.57 \pm 0.68^{\mathrm{a}}$ & $10.14 \pm 0.78^{\mathrm{a}}$ \\
Albumin $(\mathrm{gm} / \mathrm{dl})$ & $3.11 \pm 0.12$ & $3.03 \pm 0.21$ & $3.44 \pm 0.17$ \\
Globulin $(\mathrm{gm} / \mathrm{dl})$ & $3.49 \pm 0.81^{\mathrm{b}}$ & $6.54 \pm 0.62^{\mathrm{a}}$ & $6.70 \pm 0.72^{\mathrm{a}}$ \\
Albumin: Globulin ratio & $0.89 \pm 0.18^{\mathrm{a}}$ & $0.46 \pm 0.05^{\mathrm{b}}$ & $0.51 \pm 0.07^{\mathrm{b}}$ \\
Glucose (mg/dl) & $139.89 \pm 7.3$ & $125.90 \pm 7.2$ & $125.97 \pm 10.3$ \\
Urea (mg/dl) & $37.57 \pm 2.29^{\mathrm{a}}$ & $30.36 \pm 4.14^{\mathrm{b}}$ & $23.59 \pm 1.93^{\mathrm{c}}$ \\
Triglycerides (mg/dl) & $45.21 \pm 5.23$ & $52.44 \pm 10.01$ & $68.56 \pm 8.52$ \\
Cholesterol (mg/dl) & $43.76 \pm 5.41$ & $52.57 \pm 6.43$ & $59.16 \pm 9.46$ \\
\hline
\end{tabular}

${ }^{\mathrm{a}-\mathrm{c}}$ Means with different superscripts in the same row are significantly different at $\mathrm{P}<0.05$.

\section{Hematological profile}

Tables (6 and 7) show that the addition of (NSS) and (CF) to the basal diet increased $(\mathrm{P}<0.05)$ total WBC's and lymphocytes counts of ewes and lambs. On the other hand, ewes fed the unsupplemented basal diet had the highest $(\mathrm{P}<0.05)$ monocytes count compared to the supplemented groups. Neutrophils count of both ewes and lambs was not affected by these additives. RBC's count and $\mathrm{Hb}$ concentration of ewes were not affected by these additives, on the contrary both were significantly increased in lambs. 
Table 6. Hematological profile of lactating Awassi ewes as affected by dietary

\begin{tabular}{lccc} 
treatments & Means \pm SE) & \multicolumn{2}{c}{$(\mathbf{n}=7 /$ group $)$} \\
\cline { 2 - 4 } Items & \multicolumn{2}{c}{ Dietary } & \multicolumn{2}{c}{ treatments } \\
\cline { 2 - 4 } & Control & $\begin{array}{c}\text { Chamomile } \\
\text { flowers }\end{array}$ & $\begin{array}{c}\text { Nigella sativa } \\
\text { seeds }\end{array}$ \\
\hline WBC's $\left(10^{3} / \mathrm{mm}^{3}\right)$ & $83.1 \pm 3.3^{\mathrm{b}}$ & $96.9 \pm 3.3^{\mathrm{a}}$ & $91.1 \pm 3.3^{\mathrm{b}}$ \\
Lymphocytes & $28.58 \pm 1.2^{\mathrm{b}}$ & $37.50 \pm 2.7^{\mathrm{a}}$ & $34.70 \pm 1.5^{\mathrm{a}}$ \\
$\left(10^{3} / \mathrm{mm}^{3}\right)$ & $1.91 \pm 0.4^{\mathrm{a}}$ & $0.97 \pm 0.0^{\mathrm{b}}$ & $1.2 \pm 0.2^{\mathrm{b}}$ \\
Monocytes $\left(10^{3} / \mathrm{mm}^{3}\right)$ & $52.26 \pm 2.1$ & $58.43 \pm 4.8$ & $55.20 \pm 1.6$ \\
Neutrophils $\left(10^{3} / \mathrm{mm}^{3}\right)$ & $3045.7 \pm 178.3$ & $3171.0 \pm 110.7$ & $3214.3 \pm 111.7$ \\
$\mathrm{RBC}$ 's $\left(10^{6} / \mathrm{mm}^{3}\right)$ & $9.14 \pm 0.59$ & $9.23 \pm 0.34$ & $9.74 \pm 0.29$ \\
$\mathrm{Hb}(\mathrm{g} / \mathrm{dl})$ & &
\end{tabular}

${ }^{\mathrm{a}-\mathrm{c}}$ Means with different superscripts in the same row are significantly different at $P<0.05$.

Table7. Hematological profile of suckling Awassi lambs as affected by dietary

\begin{tabular}{lccc} 
treatments & \multicolumn{2}{c}{$(\mathbf{n}=7 /$ group $)$} \\
Items & \multicolumn{2}{c}{ Dietary } & \multicolumn{2}{c}{ treatments } \\
\cline { 2 - 4 } & Control & $\begin{array}{c}\text { Chamomile } \\
\text { flowers }\end{array}$ & $\begin{array}{c}\text { Nigella sativa } \\
\text { seeds }\end{array}$ \\
\hline WBC's $\left(10^{3} / \mathrm{mm}^{3}\right)$ & $96.20 \pm 1.1^{\mathrm{b}}$ & $99.30 \pm 1.1^{\mathrm{a}}$ & $98.90 \pm 1.1^{\mathrm{a}}$ \\
Lymphocytes $\left(10^{3} / \mathrm{mm}^{3}\right)$ & $28.09 \pm 1.8^{\mathrm{b}}$ & $34.46 \pm 1.6^{\mathrm{a}}$ & $36.21 \pm 3.3^{\mathrm{a}}$ \\
Monocytes $\left(10^{3} / \mathrm{mm}^{3}\right)$ & $1.44 \pm 0.5$ & $1.99 \pm 0.4$ & $1.77 \pm 0.4$ \\
Neutrophils $\left(10^{3} / \mathrm{mm}^{3}\right)$ & $65.70 \pm 2.9^{\mathrm{a}}$ & $61.53 \pm 1.7^{\mathrm{b}}$ & $59.94 \pm 3.5^{\mathrm{b}}$ \\
Eiosinophils $\left(10^{3} / \mathrm{mm}^{3}\right)$ & $0.96 \pm 0.3$ & $1.32 \pm 0.3$ & $0.98 \pm 0.4$ \\
$\mathrm{RBC}$ 's $\left(10^{6} / \mathrm{mm}^{3}\right)$ & $3550.0 \pm 54.6^{\mathrm{b}}$ & $3757.2 \pm 24.1^{\mathrm{a}}$ & $3814.3 \pm 86.4^{\mathrm{a}}$ \\
$\mathrm{Hb}(\mathrm{g} / \mathrm{dl})$ & $10.60 \pm 0.1^{\mathrm{b}}$ & $11.10 \pm 0.1^{\mathrm{a}}$ & $11.20 \pm 0.1^{\mathrm{a}}$ \\
\hline
\end{tabular}

${ }^{\mathrm{a}-\mathrm{b}}$ Means with different superscripts in the same row are significantly different at $P<0.05$.

\section{DISCUSSION}

\section{Milk production and composition}

This study showed that the addition of either (CF) or (NSS) to basal ration of Awassi ewes improved milk production and composition in terms of milk yield, total protein, ash and solids not-fat percentages. On the other hand it extended the lactation period. (CF) had significantly better effect compared to (NSS) treatment.

Concerning (NSS), the increase in milk yield and lactation period may be attributed to the galactogoetic effect of the active components that (NSS) may contain. Singh et al. (1993) discovered that the positive effect of galactogogues on milk production may be due to the decrease in circulating biogenic amines such as, histamine, tryptamine and tyramine in blood which are known to cause excessive release of catecholamines in mobile pool leading to suspension of milk secretion as well as causing indigestion by inhibiting the ruminal mobility and absorption. Composition and properties of (NSS) have been fairly investigated by El-Dakhakhny (1963), EL-Alfy et al. (1975), Mahmoud (1993) and Houghton et al. (1995). These researchers reported that (NSS) oils have; anti-bacterial, anti-fungal, antiinflammatory and anti- histaminic effects. Mahmoud (1993) found that (NSS), 
particularly its oils, showed anti-bacterial activity against 5 strains of Listeria monocytogenes, which may enhance the performance of animal. Proximate analysis showed that (NSS) contains 23.5-33.2\% carbohydrate, 20-27\% proteins and 34.538.7\% lipids (Abdel-Aal and Attia, 1993; Hedaya, 1996; Salem, 2001). It has been reported that most of (NSS) properties are, mainly, attributed to thymoquinone, the main constituent of (NSS) volatile oil (Badary et al., 1998) and nigellimine N-oxide, as isoquinoline alkaloid (Ghazanfar, 1994). EL-Komy (1996) found that (NSS) increased mammary gland development in rats thus milk yield is increased at different stages of lactation. Therefore, (NSS) appears to be a potential multipurpose feed additive and may be promising in improving sheep and lambs performance.

Chamomile flowers supplementation increased milk yield and lactation period of Awassi ewes. Both agricultural and medical literatures were searched for studies that examined (CF) effects on milk production and composition. However, one article by Allam, et al. (1999) crossed our search, where they reported that (CF) improved daily milk yield of goats, by $10 \%$, compared to other medicinal plants, over the control treatment. However, the lack of information about the use of (CF) as a feed additive to sheep rations make it difficult to understand the mechanism through which milk yield and lactation period increased. The present results of increase in milk yield and lactation period resulting from (CF) supplementation is, probably, due to the remarkable vasodilator action of chamomile essential oil, particularly bisabolol and bisabolol oxides, (Achterrath-Tuckermann et al., 1980) with the fact that vasodilator action increases the blood flow in blood vessels which normally supplies the mammary glands by all components required for milk production.

Several researchers found that the use of (NSS) and (CF) as feed additives increased milk yield and maintained relatively high level of persistency (Zeid, 1998; Kholif, 2001; Shehata et al., 2004).

\section{Lamb growth performance}

The addition of either (CF) or (NSS) to the basal diet (BD) improved significantly lamb growth performance in terms of WW and ADG. These favorable effects of (CF) and (NSS) could be related to their high nutritive biological value.

Previous studies in this regards reported that 15 amino acids make-up the proteins of (NSS) (Takruri and Dameh, 1998). Moreover, Babyan et al. (1978) found that (NSS) contains a mixture of essential fatty acids particularly, linolenic, oleic and linoleic acids that is necessary for good body growth. One more factor that may explain the favorable effects from using (NSS) as feed additive is its stimulating effect on the animal digestive system as stated by Ramakrishna et al. (2003). It has been reported that (NSS) has also choleric effects which produce a definite increase in bile flow (Mahfouz and EL-Dakhakhny, 1960). This flow is an emulsifying agent that activates the pancreatic lipase that aids fat digestion and fat-soluble vitamins absorption (Crossland, 1980).

Concerning (CF), it has been reported that its essential oils have anti-ulcer effect (Szelenyi et al., 1979), this maintains normal proper structure and function of the digestive tract thus improving digestion and absorption of nutrients that may explain enhancements of lambs' growth. Unfortunately, scarcities of researchers are noted in this field.

The present findings are consistent with the previous findings of Zeid (1998) who reported that feeding herbs, of which one of them was (NSS), improved nutrient 
digestibility by $8-12 \%, 6-16 \%, 1-12 \%$ and $7-27 \%$ for; DM, OM, CP and CF respectively. EL-Hossieny et al. (2000) concluded that using (CF) and (NSS) as a natural feed additives increase BW, WW and ADG of suckling and growing lambs.

\section{Blood relevant metabolites}

Concentrations of blood relevant metabolites were in harmony with the findings of Zeid (1998) who reported that average concentrations of Zaraibi goat blood albumin and triglycerides were not significantly affected by the addition of herbs of which are (NSS) and (CF). Anyhow, the same author found that total lipids concentration was significantly decreased by the addition of $60 \mathrm{mg}$ (CF) / Kg LBW to the control ration. Nevertheless, increase in total protein and globulin of these Awassi ewes and lambs serum might be attributed to the high nutritive biological values of these herbs, particularly, protein and amino acids. In this context, Takruri and Dameh (1998) reported 15 amino acids make-up the protein of (NSS) that are required for good performance. Several researchers discovered that different herbs of which one of them was (NSS) stimulated animal digestive system particularly the digestion of protein and fat (Cabuk et al., 2003 and Rammakrishna et al., 2003). The present results also support the finding of EL-Hossieny et al. (2000) who reported that serum total protein and globulin were higher $(\mathrm{P}<0.05)$ by the addition of (NSS). The reduction in serum cholesterol of Awassi ewes in the present study may be due to the reduction effect of thymoquinone and monounsaturated fatty acids (MUFA) on the synthesis of cholesterol by hepatocytes or fractional reabsorption from the small intestine (Brunton, 1999), or may be due to the stimulating effect of UFA on the cholesterol excretion into the intestine and the oxidation of cholesterol to bile acids (Khodary et al., 1996).

\section{Blood hematological profile}

Blood hematological profile is an important index of the physiological state of the animal. Esonus et al. (2001) stated that hematological profile reflects the physiological responsiveness of the animal to its internal and external environments including feeds and feeding. Previous researchers proved that effect of various feeds on the hematological profile of livestock and stated that unconventional sources of feeds affect animal physiology (Emenalom and Udebibie, 1998). Mahfouze and ELDakhakhny (1960) discovered that essential oils of (NSS) contain crystalline compounds, named nigellone or thymoquinone, which have protective effect against diseases. The present results, clearly, showed that the addition of medicinal plants (CF) and (NSS) significantly increased total WBC's and lymphocytes counts of these lactating ewes and suckling lambs. Similar trends of results were also noticed in RBC's counts and $\mathrm{Hb}$ concentration in lamb blood.

It is believed that the favorable effect obtained from using (CF) and (NSS) as natural growth promoters may be due to the main components of these medicinal plants, particularly, their essential oils. Zaher et al. (2008) suggested that crushed (NSS) has immunestimulant effect when used as remedies for disease with variant degrees of success. Chamomile has inhibited both positive and negative bacterial activity with salmonella typhimurium and staphylococcus aureus. About 120 chemical constituents have been identified in chamomile as secondary metabolites, including 28 terpenoids, 36 flavonoids and 52 additional compounds with potential pharmacological activity (Mann and Staba, 1992). Unfortunately, there is a lack in 
the literatures that explain how the active components of (CF) and (NSS) works or affects blood hematological profile of ewes or lambs.

\section{CONCLUSION}

It could be concluded that (CF) and (NSS) as feed additives may have a beneficial effect on sheep performance and may replace traditional growth promoters. $(\mathrm{CF})$ and (NSS) are characterized by being natural edible promoters, which have no side effect on animals and consequently on humans. However, further detailed studies must be performed on using different levels of (CF) and (NSS) to evaluate the suitable level that can be used in sheep rations.

\section{REFERENCES}

Abdel-Aal, E.S. and R.S. Attia, 1993. Characterization of black cumin (Nigella sativa) seeds. 1. Chemical composition and lipids. Alex. Sci. Exch. 14: 467-482.

Achterrath-Tuckermann, U., R. Kunde, E. Flaskamp, O. Isaac and K. Thiemer, 1980. Pharmacological Investigations with Compounds of Chamomile V. Investigations on the Spasmolytic Effect of Compounds of Chamomile and Kamillosan® on the Isolated Guinea Pig lleum. Planta Med. 39: 38-50.

Allam, S.M., H.M. EL-Hossieny; A.M. Abdel-Gawad, S.A. EL-Saadany, A.M.M. Zeid, 1999. Medicinal herbs and plants as food additives for ruminants. 1. Effect of using some medicinal herbs and plants as feed additives on Zaraibi goat performance. Egyptian J. Nut. And Feeds (Special Issue). 2: 349-365.

Babyan, V.K., D. Koottungal and G. A. Halaby, 1978. Proximate analysis, fatty acid composition of Nigella sativa L. seeds. J. Food Sci. 43: 1314-1315.

Badary, O.A., A.AL-Shabanah, M.N. Nagi, A.M.AL-Bekairi, M.A. Almazar, 1998. Acute and subchronic toxicity of thymoquinone in mice. Drug Development Res. 44: 56-61.

Barnett, A.J.G and Abd EL-Tawab, 1957. Determination of Lactose in milk and cheese. J. Sc. Food Agric. 8: 437.

Brunton, L.I., 1999. Agents affecting gastrointestinal water flux and mortality, digestion and bile acids, The Pharmacological Basis of Therapeutic, 8th (Eds), Pregman Press.

Cabuk, M., A. Alcicek, M. Bozkurt, N. Imre, 2003. Antimicrobial properties of the essential oils isolated from aromatic plants and using possibility as alternative feed additives. 11. National Animal Nutrition Congress, 18-20. September, pp 184-187.

Crossland, J., 1980. Lewiss Pharmacology. $5^{\text {th }}$ Ed, Churchill Livingston, London, N.Y., pp. 656-657.

EL-Alfy, T.S., H.M. EL-Fatatry, M.A.Toama, 1975. Isolation and structure assignment of an antimicrobial principle from the volatile oil of Nigella sativa L. seeds. Pharmazia. 30, 2: 109-111.

EL-Dakhakhny, M., 1963. Studies on the chemical constitution of Egyptian Nigella sativa L. seeds II. The essential oil. Planta Med. 11: 465-470.

EL-Hossieny, H.M., S.M. Allam, S.A. EL-Saadany, A.M. Abdel-Gawad, A.M. Zeid, 2000. Medicinal herbs and plants as food additives for ruminants. 2. Effect of 
using some medicinal herbs on growth performance of Zaraibi kids. Proc. Conf. Anim. Prod. Sakha, Kafr AL-Sheikh, Egypt. 189-199.

EL-Komy, A.G., 1996. Effect of black seeds (Nigella sativa L.) during pregnancy and lactation on mammary gland development in rat. Alexandria J. Agric. Res. 41: 63-74.

Emenalom, O.O. and A.B.I. Udedibie, 1998. Effect of dietary raw, cooked, toasted mucuna pruriens seeds (velvet bean) on the performance of finisher broilers. Nig. J. Anim. Prod. 25: 115-119.

Esonu, B.O.; O.O. Fmenalom; A.B.I. Udedibie, U. Herbert, C.F. Ekpor, I.C. Okolie; F.C.Iheukwumere, 2001. Performance and blood chemistry of weaner pigs fed raw mucuna (velvet bean). Tropical Animal Production Investigations. 4: 49-54.

Ghazanfar, Sh., 1994. Hand book of Arabian medicinal plants. CRC Press, Boca Raton, Ann Arbor, London, Tokyo. pp. 117-180.

Hedaya, S.A., 1996. Effect of Nigella sativa seeds (black seeds) extract on some hematological and biochemical parameters in rats. Frst. Sci. Cong. Fac. Vet. Med. Alex. Univ. 17-19 Oct. Alex. Egypt.

Houghton, P.J., R. Zarka, B. De La Heras and R.J. Hoult, 1995. Fixed oil of Nigella sativa and derived thymoquinone inhibit eicosanoid generation in leukocytes and membrane lipid peroxideation. Planta Medica, 61: 33-36.

Khodary, R.M., M.H.EL-Ezzawy; I.R. Hamdy, 1996. Effect of Nigella sativa on egg production, hatchability percentage and some biochemical values in laying hens with references to fertility in cockerels. Proc. Of $7^{\text {th }}$ Sci. Cong., Fac. Vet. Med. Assuit. Univ., 17-19 Nov. Egypt: 91-106.

Kholif, A.M., 2001. Medicinal plant seeds supplementation to goat diets and their effect on milk yield and milk composition. Proc. $3^{\text {rd }}$ all Africa Conf. Cnim. Agric. and $11^{\text {th }}$ conf. Egyptian Soc. Anim. Prod. Alexandria, Egypt. 6-9 Nov. 2000. 197-200.

Kronfeld, D.S., 1991. Bovine somatotropin. Journal of the American Medical Association. 265, 11: 1389.

Ling, E.R., 1963. A text book of dairy chemistry. Champan and Hall, Ltd. London.

Lurdi, R.S., 1993. Scope for the application of BST for boosting milk production in India. India Dairyman. 445: 17.

Mahfouz, M. and M. EL-Dakhakhny, 1960. Some chemical and pharmacological properties of the new antiasthmatic drug "Nigellone". Egypt. Pharm. Bull. 24: 411-424.

Mahmoud, H.M.A., 1993. Inhibitory action of black cumin (Nigella sativa L.) against Listeria monocytogenes. Alexandria J. Agric. Res. 38: 123-134.

Mann, C. and E.J. Staba, 1992. The chemistry, physiology and commercial Formulation of Chamomile. In: Craker, L.E. and Simon, J.E. (Eds). Herbs, Spices and Medicinal plants. Recent Advances in Botany, Horticulture and Pharmacology. Food Product Press, New York, USA. 1: 235-280.

Rammakrishna, R.R., K. Platel and K. Srinivasan, 2003. In vitro influence of species and spice-active principles on digestive enzymes of rat pancreas and small intestine. Nahrung. 47: 408-412.

Salem, M.A., 2001. Effect of heat treatments on Nigella sativa seeds characteristics 1. Some physiological and chemical properties of Nigella sativa seeds oil. J. Agric. Res. Tanta Univ. 27: 471-486. 
Shehata, E.I., M.E. Ahmad, H. Ferial, Abd-EL-Rasoul, F. Faten, Abou-Ammo, R.AL-Ashwal, 2004. Effect of feeding a medicinal herb, chamomile flower on production and hygiene of goat milk. Egyptian J. Nutrition and Feeds. 7, 2: 109117.

Singh, N., M.A. Akbar; M.R. Kumari, 1993. Effect of some commonly used galactagogues on different blood biochemical constituents of lactating buffaloes. Indian Vet. Med. J., 70: 441.

SPSS Inc., 2001. SPSS for Windows 10.0 Base System user's guide, release 10.0 SPSS Inc. Printed in the USA.

Szelenyi, I., O. Issac and K. Thiemer, 1979. Pharmacological experiments with compounds of chamomile III. Experimental studies of the ulceroprotective effect of chamomile. Planta Med. 35: 218-227.

Takruri, H.R.H. and M.A.F. Dameh, 1998. Study of the nutritional value of black cumin seeds (Nigella sativa L). J. Sci. Food Agric. 76: 404-410.

Tiwari, S.P., R. Lal, S.P. Arora, M.P. Narange, 1993. Effect of feeding anise seedherb combination on milk production in crossbred cows. Indian J. Anim. Nutr. 10: $115-117$.

Vihan, V.S. and H.S. Panwar, 1987. Galactopoietic effect of Nigella sativa (HKalonji) in clinical cases of aglactia in goats. Indian Vet. J., 64: 347-349.

Wintrobe, M.M., 1976. Classics: Macroscopic examination of the blood by M.M. Wintrobe, M.D., Ph.D. The American journal of the medical sciences. 271: 1, 90-101.

Zaher,K.S., W.M. Ahmad and S.N. Zerizer, 2008. Observations on the biological effects of black cumin seeds (Nigella sativa) and green tea (Camellia sinensis). Glob. Vet. 2, 198-204.

Zeid, A.M.M., 1998. Effect of using medicinal plant on goat performance. Ph.D. Thesis. Fac. Agric. Cairo University. 
تأثير إضافة بعض النباتات الطبية لغذاء نعاج أغنام العواسى على إنتاج الحليب وتركيبه، نمو الحملان ويعض مكونات الام

صفاء سعيد الغصين قسم الإنتاج الحيواني، كلية الزراعة، جامعة جش الأهلية، جرش، الأردن

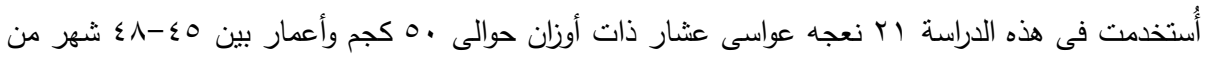
مزرعة الكلية فى الفترة الأخيرة من الحمل وقسمت إلى بـ مجموعات:

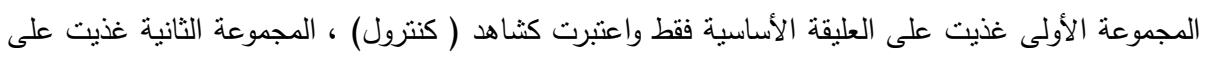

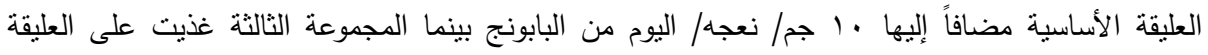

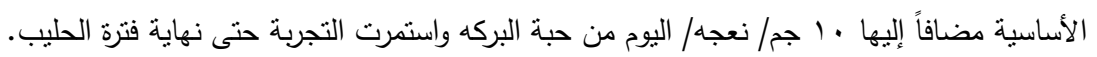

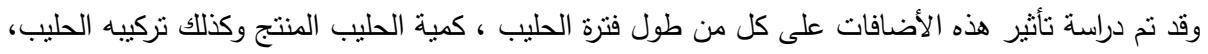
بالإضافة إلى بعض مكونات الدم وأيضاً نمو الحملان.

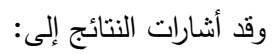

أ- ظهور زيادة معنوية فى كمية الحليب وزيادة فترة الحليب بين المعاملات الثلاثة لصالح معاملة البابونج يليها حبة البركة مقارنة بالثاهد.

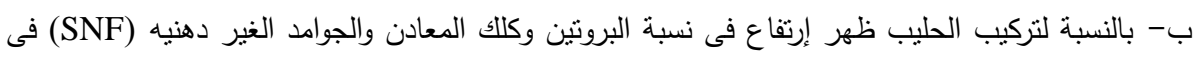

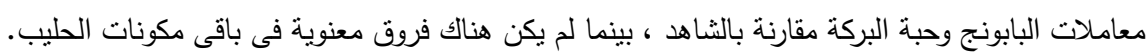

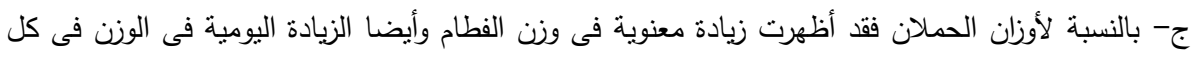
من معاملة البابونج وحبة البركة مقارنة بالثاهد.

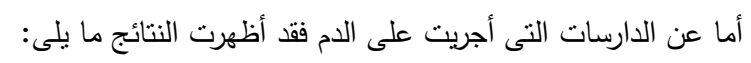
1- إرتفاع تركيز كل من البروتين الكلى والجلوبيولين فى الدم لكل من النعاج والحملان فى معاملات البابونج وحبة البركة مقارنة بالثاهد. r- نسبة الألبيومين: الجلوبيولين أظهرت إرتفاعاً فى معاملات الإضافة بالنسبة للنعاج وانخفاضا فى نفس المعاملات بالنسبة للحملان. r- مستويات الكوليستيرول فى الدم أظهرت انخفاضا معنوياً فى معاملات البابونج وحبه البركه مقارنة بالثاهد بالنسبة للنعاج وإنخفاض غير معنوى بالنسبة للحملان.

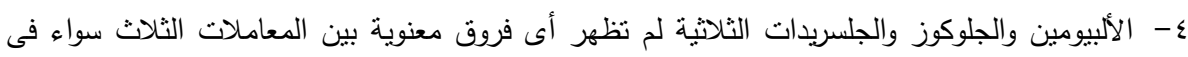
النعاج أو الحملان. ه- اليوريا أظهرت انخفاض معنوى فى معاملات الإضافة مقارنة بالثاهد بالنسبة للحملان وغير معنوية بالنسبة للنعاج. צ- إرتفاع معنوى فى عدد كرات الدم البيضاء والكرات المفيه فى معاملة البابونج وحبه البركة مقارنة بالثاهد بالنسبة لكل من النعاج والحملان. 
V- إرتفاع معنوى فى عدد كرات الدم الحمراء وكذللك تركيز الهيموجلوبين فى معاملة البابونج وحبة البركة مقارنة بالثاهد بالنسبة للحملان بينما للنعاج كانت الفروق غير معنوية.

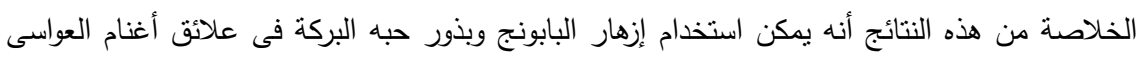
كمحفزات طبيعية لإدرار اللبن وكذلك كمنشطات لنمو الحملان لما لها من تأثير إيجابى على كل من كميه الحليب وتركيبه وطول فترة الحليب ومن ثم على نمو الحملان وكذلك إرتفاع المناعة الحيوية. 